Article

\title{
Essential and Recovery Oils from Matricaria chamomilla Flowers as Environmentally Friendly Fungicides Against Four Fungi Isolated from Cultural Heritage Objects
}

\author{
Mervat EL-Hefny ${ }^{1, *}$, Wael A.A. Abo Elgat ${ }^{2}{ }^{(0)}$, Asma A. Al-Huqail ${ }^{3, *}$ and Hayssam M. Ali ${ }^{3}$ \\ 1 Department of Floriculture, Ornamental Horticulture and Garden Design, Faculty of Agriculture (El-Shatby), \\ Alexandria University, Alexandria 21545, Egypt \\ 2 Restoration department, High Institute of Tourism, Hotel Management and Restoration, Abukir, \\ Alexandria 21526, Egypt; watsat20@yahoo.com \\ 3 Chair of Climate Change, Environmental Development and Vegetation Cover, Department of Botany and \\ Microbiology, College of Science, King Saud University, Riyadh 11451, Saudi Arabia; hayhassan@ksu.edu.sa \\ * Correspondence: mervat.mohamed@alexu.edu.eg (M.E.-H.); aalhuqail@ksu.edu.sa (A.A.A.-H.)
}

Received: 2 October 2019; Accepted: 29 October 2019; Published: 4 November 2019

check for updates

\begin{abstract}
Recovery oils, obtained from the hydro-distillation of the fresh flowers of Matricaria chamomilla, as well as essential oils, were studied for their environmental purposes in cultural heritage. These oils were assayed for their antifungal activity against the growth of four molds isolated from archaeological manuscripts (Aspergillus niger), museum gypsum board Antique (A. flavus), museum archaeological tissue (A. terreus), and museum organic materials (Fusarium culmorum) of cultural heritage objects. Oils were applied to inhibit the growth of fungi at amounts of 25, 50, 75 and, $100 \mu \mathrm{L} / \mathrm{mL}$, and compared with negative controls $(0 \mu \mathrm{L} / \mathrm{mL}$ ) or positive controls (Sertaconazol $3 \mathrm{~g} / \mathrm{L})$. Using GC/MS analysis, the main chemical compounds identified in the essential oil were (Z)- $\beta$-farnesene (27\%), $D$-limonene (15.25\%), and $\alpha$-bisabolol oxide A (14.9\%), while the compounds identified in the recovery oil were $\alpha$-bisabolol oxide A (18.6\%), D-limonene (8.82\%), and $\alpha$-bisabolol oxide B (7.13\%). A low amount of chamazulene was observed in both essential and recovery oils, with amounts of $0.73 \%$ and $3.50 \%$, respectively. Recovery oil, at a concentration of 75 and $100 \mu \mathrm{L} / \mathrm{mL}$, showed fungal mycelial inhibition (FMI) percentage for the growth of $A$. niger, with values of $78 \%$ and $85 \%$, respectively. At a concentration of $100 \mu \mathrm{L} / \mathrm{mL}$, both oils showed $100 \%$ FMI of $A$. terreus. Oils showed weak activity against the growth of $A$. flavus. Essential oils at $100 \mu \mathrm{L} / \mathrm{mL}$ had good activity against the growth of F. culmorum, with FMI of $86.6 \%$. The results suggest the potential use of essential and recovery oils from $M$. chamomilla fresh flowers as environmentally friendly bio-fungicides.
\end{abstract}

Keywords: antifungal activity; chamazulene; GC/MS-analysis; Matricaria chamomilla; flower oils; cultural heritage

\section{Introduction}

In domestic environmental conditions, fungi are known as a major biodeteriogens of cultural heritage. Fungi are able to colonize and degrade materials (wood, paper, textiles, leather, plastic, stones, metal, and clay) that have been used for the construction of cultural heritage sites, such as monuments and artifacts, causing stains in their surfaces or changing their morphological characterizations [1-10]. Therefore, the chemical treatment applications used in cultural heritage conservation must be non-toxic and non-destructive $[2,11]$. 
Natural extracts and essential oils (EOs) from aromatic and medicinal plants have been reported to have potential antifungal activities against the growth of certain mold species, such as Aspergillus, Fusarium, Alternaria, Rhizoctonia, and Chaetomium, [12-19]. Morus alba heartwood and Maclura pomifera bark methanoilc extracts had a significant effect on the linear growth of T. harzianum [5]. Wood specimens, treated with Pinus rigida heartwood extract or essential oil inhibited growth of Alt. alternata, F. subglutinans, C. globosum, A. niger, and T. viride $[9,10]$. Melia azedarach wood, treated with $3 \%$ methanolic extract of $M$. paradisiaca peel, showed strong antifungal activity against F. culmorum and R. solani [12]. EO, extracted from different parts of Citrus aurantium with D-limonene being the principal compound, showed good antibacterial activity [13]. Leucaena leucocephala wood, treated with acetone extract from either the inner or outer bark of Acer saccharum var. saccharum in combination with citric acid showed antifungal activity against T. viride, F. subglutinans, and A. niger [14]. Amongst the n-hexane oily extracts, $M$. chamomilla flowers extract treated wood samples observed the lowest activity against the growth of F. culmorum, P. chrysogenum and R. solani [15].

Chemical compounds, related to EOs and phenolic and flavonoid, prevent fungal growth through the inhibition of mycelia, conidial production, and sporulation of fungi [16]. EOs from different plants have been reported to inhibit the fungal pathogens of $F$. moniliforme, F. oxysporum, Rhizoctonia solani, A. solani, and Aspergillus sp. [17-19].

Chamomile (Matricaria recutita L., syn: M. chamomilla or M. suaveolens), is one of the most important medicinal herbs native to southern and Eastern Europe, growing in Russia, Germany, France, Hungary, and Brazil. It can also be found in North Africa [20,21]. Chamomile has been used in herbal remedies for thousands of years, having been known in ancient Egypt, Greece, and Rome [22]. Flowers have a blue EO content, ranging from $0.2 \%$ to $1.9 \%$, which has been used in various applications $[23,24]$. Extracts and EOs of $M$. chamomilla exhibit a wide range of biological activities, such as antimicrobial, antioxidant and anti-inflammatory properties $[25,26]$.

Chamazulene, a sesquiterpene compound responsible for the blue EO of chamomile, is used in the pharmaceutical and cosmetic industries [27]. The amount of chamazulene in various chamomiles depends on the origin and age of the material and was found to decrease during flowers' storage [28]. Different studies showed the presence of the following compounds in the flower or root EO chamazulene: $\alpha$-bisabolol, $(E)-\beta$-farnesene, germacrene $\mathrm{D}$, spathulenol, $(E)$-nerolidol, farnesene, geraniol, $\beta$-elemene, linalool, nerol, $\tau$-cadinol, $\tau$-muurolol, $\beta$-caryophyllene, cis-caryophyllene, and caryophyllene oxide [15,29-31].

The main compounds identified in the EOs of flowers from $M$. chamomilla were chamazulene, trans-trans-farnesol, isopropyl hexadecanoate, and $E-\beta$-farnesol. These have been observed to have potential antifungal activity [32]. Bisabolol oxide A, (Z)- $\beta$-farnesene, 4-isopropenyl-1-methyl-cyclohexene, and chamazulene were reported as the main compounds in an $n$-hexane extract of air-dried flowers of $M$. recutita [15], demonstrating good antifungal activity. The identified compound of $\alpha$-bisabolol, from the EO of M. chamomilla flowers, has shown good antimicrobial properties [33,34], whereas $\alpha$-bisabolol and chamazulene are considered antiseptic [35].

The present study aimed to evaluate the effects of essential and recovery oils from $M$. chamomilla (fresh flowers) on the growth of four fungi, isolated from cultural heritage.

\section{Materials and Methods}

\subsection{Extraction of Essential and Recovery Oils}

Flowers of Matricaria chamomilla were collected during March 2019, from Alexandria, Egypt. About $100 \mathrm{~g}$ of fresh flowers were put in a $2 \mathrm{~L}$ flask containing $1500 \mathrm{~mL}$ distilled water, then their essential oil was extracted by hydrodistillation in a Clevenger apparatus for $2 \mathrm{~h}$ [13]. The distillate was mixed with $n$-hexane, to extract the recovery oil dissolved in water (hydrosol) using a funnel separator. The percentages of the oils were $1.5 \%$ and $1.9 \%$, from EO and recovery oils, respectively. 


\subsection{Tested Fungal Isolates}

All fungi used in this study were isolated from different organic and inorganic substrata of cultural heritage objects in Egypt (Table 1). For DNA extraction, each isolate was grown in potato dextrose broth for three to four days. The mycelia of each isolate were harvested and processed for genomic DNA extraction, using a protocol published by Saitoh [36]. Analyses of DNA sequences of partial ITS gene were performed according to our previous published article [37].

Table 1. Fungal isolates chosen for the study of the antifungal activity of essential and recovery oils from Matricaria chamomilla flowers.

\begin{tabular}{cccc}
\hline Isolates & Substrata & Strain & Accession Number \\
\hline Aspergillus flavus & Museum Gypsum board Antique & AFl375 & MH355958 \\
\hline Aspergillus niger & Archaeological Manuscripts & FC24771 & MH355955 \\
\hline Aspergillus terreus & Museum archaeological tissue & Y.H. Yeh V0103 & MH355953 \\
\hline Fusarium culmorum & Museum organic materials & CBS 128537 & MH355954 \\
\hline
\end{tabular}

\subsection{GC-MS Analysis of Essential Oil and the n-Hexane Recovered Oil}

The essential oil and $n$-hexane recovered oil from flowers of Matricaria chamomilla were analyzed for their chemical constitutes, using Focus GC-DSQ Mass Spectrometer (Thermo Scientific, Austin, TX, USA) with a direct capillary column TG-5MS (30 m $\times 0.25 \mathrm{~mm} \times 0.25 \mu \mathrm{m}$ film thickness) apparatus, at Atomic and Molecular Physics Unit, Experimental Nuclear Physics Department, Nuclear Research Centre, Egyptian Atomic Energy Authority, Inshas, Cairo, Egypt. The column oven temperature programs were initially held at $45^{\circ} \mathrm{C}$, and then increased by $5^{\circ} \mathrm{C} / \mathrm{min}$ to $200{ }^{\circ} \mathrm{C}$ hold for $5 \mathrm{~min}$, and then increased to $300^{\circ} \mathrm{C}$, with 30 increments of $5^{\circ} \mathrm{C} / \mathrm{min}$ [15].

The compounds were identified through a comparison of their retention times and mass spectra with those of the WILEY 09 and NIST 11 mass spectral database. Further confirmation of chemical compounds was reported by measuring the Standard Index and Reverse Standard Index with Xcalibur 3.0 data system of GC/MS, where the value $\geq 650$ is acceptable to confirm the compounds $[14,15,38]$.

\subsection{Antifungal Activity of Essential and Recovery Oils}

The antifungal activity of oils were measured against the growth of A. niger, A. terreus, A. flavus, and F. culmorum. Oils of $M$. chamomilla were dissolved in a mixture of dimethyl sulfoxide (DMSO) $10 \%$, and Tween 40 and distilled water (1:0.5:1) were added to a warm potato dextrose agar (PDA) medium $\left(40{ }^{\circ} \mathrm{C}\right.$ to $\left.45^{\circ} \mathrm{C}\right)$, at a concentration of $25 \mu \mathrm{L} / \mathrm{mL}, 50 \mu \mathrm{L} / \mathrm{mL}, 75 \mu \mathrm{L} / \mathrm{mL}$, and $100 \mu \mathrm{L} / \mathrm{mL}$, before immediately being poured into $9 \mathrm{~cm}$ Petri dishes. Using a sterile pipette, each Petri dish was given exactly $20 \mathrm{~mm}$ of a treated PDA medium. Sertaconazol $3 \mathrm{~g} / \mathrm{L}$ (standard antibiotic) was used as a positive control. The negative control treatment contained DMSO 10\%, Tween 40, and distilled water (1:0.5:1). The mixture of dilution was used as a negative control. Each treatment was tested in triplicate. A mycelial disc, with a $9 \mathrm{~mm}$ diameter of the pathogenic fungi from a seven-day-old colony, was transferred to the center of the treated PDA dishes and controls.

14 days from the incubation period, at $26 \pm 1{ }^{\circ} \mathrm{C}$, the inhibition percentage of mycelial growth was calculated using the following equation [39]:

$$
\text { Mycelial growth inhibition }(\%)=\left[\left(\mathrm{A}_{c}-\mathrm{A}_{t}\right) / \mathrm{A}_{c}\right] \times 100
$$

where $\mathrm{A}_{c}$ and $\mathrm{A}_{t}$ represent the average diameters of the fungal colony of control and treatment, respectively. 


\subsection{Statistical Analysis}

Results of the inhibition percentage of the diameter growth for each fungus were statistically analyzed based on two factors (oil type and oil amount) using analysis of variance, SAS system [40]. The differences between the mean of each treatment were recorded using $\mathrm{LSD}_{0.05}$.

\section{Results}

\subsection{Visual Observation of Fungal Inhibition}

Figures 1-4 show the visual observation of the inhibition in growth of Aspergillus flavus, A. niger, A. terreus, and Fusarium culmorum by the application of four amounts of both oils. It can be seen that upon increasing oil amount, the inhibition of fungal mycilial growth increased. No inhibition of fungal growth was shown in the plates with negative control treatment (without oils). Plates inoculated with each fungus and treated with the positive control showed good inhibition of the fungal mycilial growth.

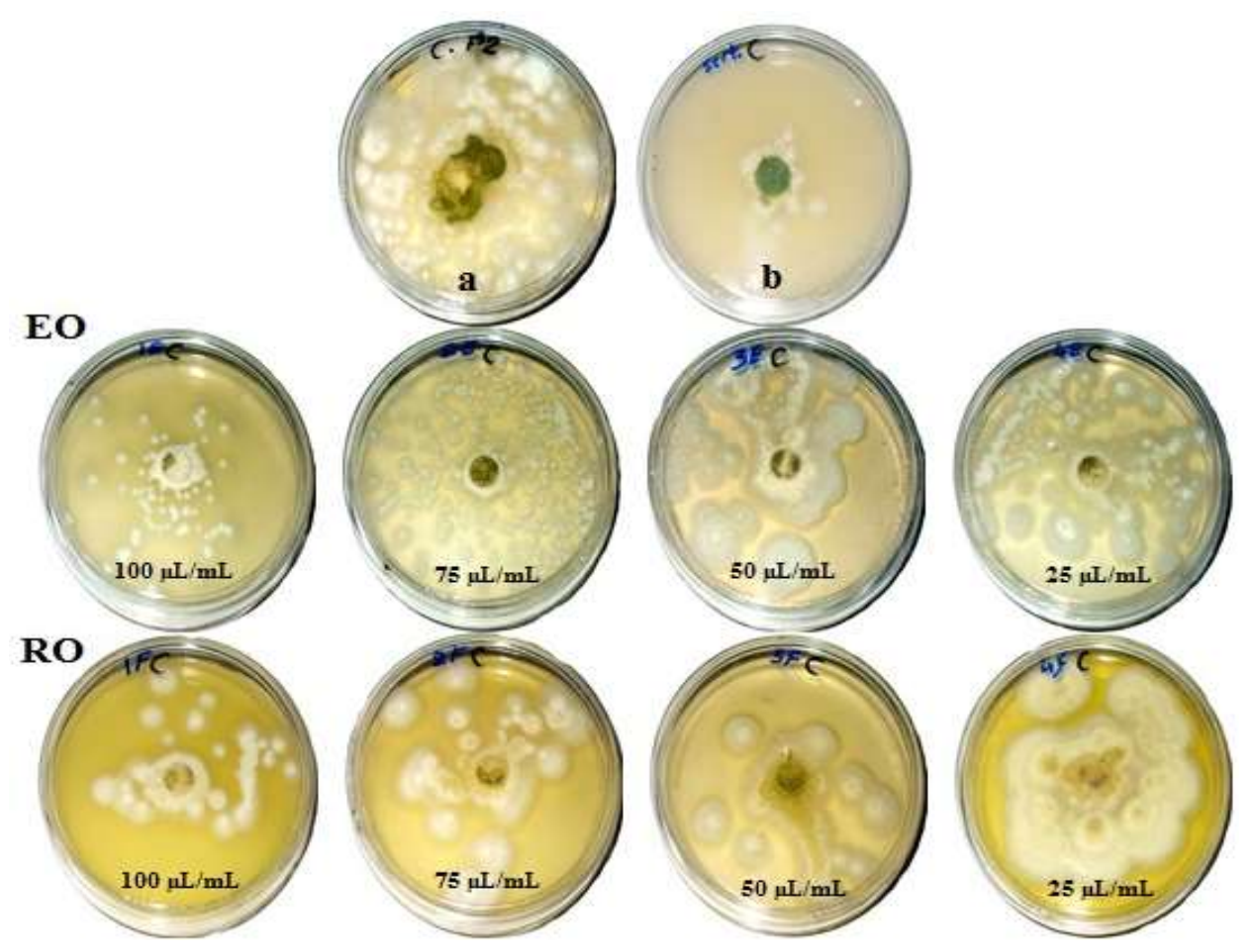

Figure 1. Visual observation of the antifungal activities of essential (EO) and recovery (RO) oils from M. chamomilla (fresh flowers) against the growth of Aspergillus flavus. (a) Negative control $(0 \mu \mathrm{L} / \mathrm{mL})$; (b) Positive control (Sertaconazol $3 \mathrm{~g} / \mathrm{L}$ ). 


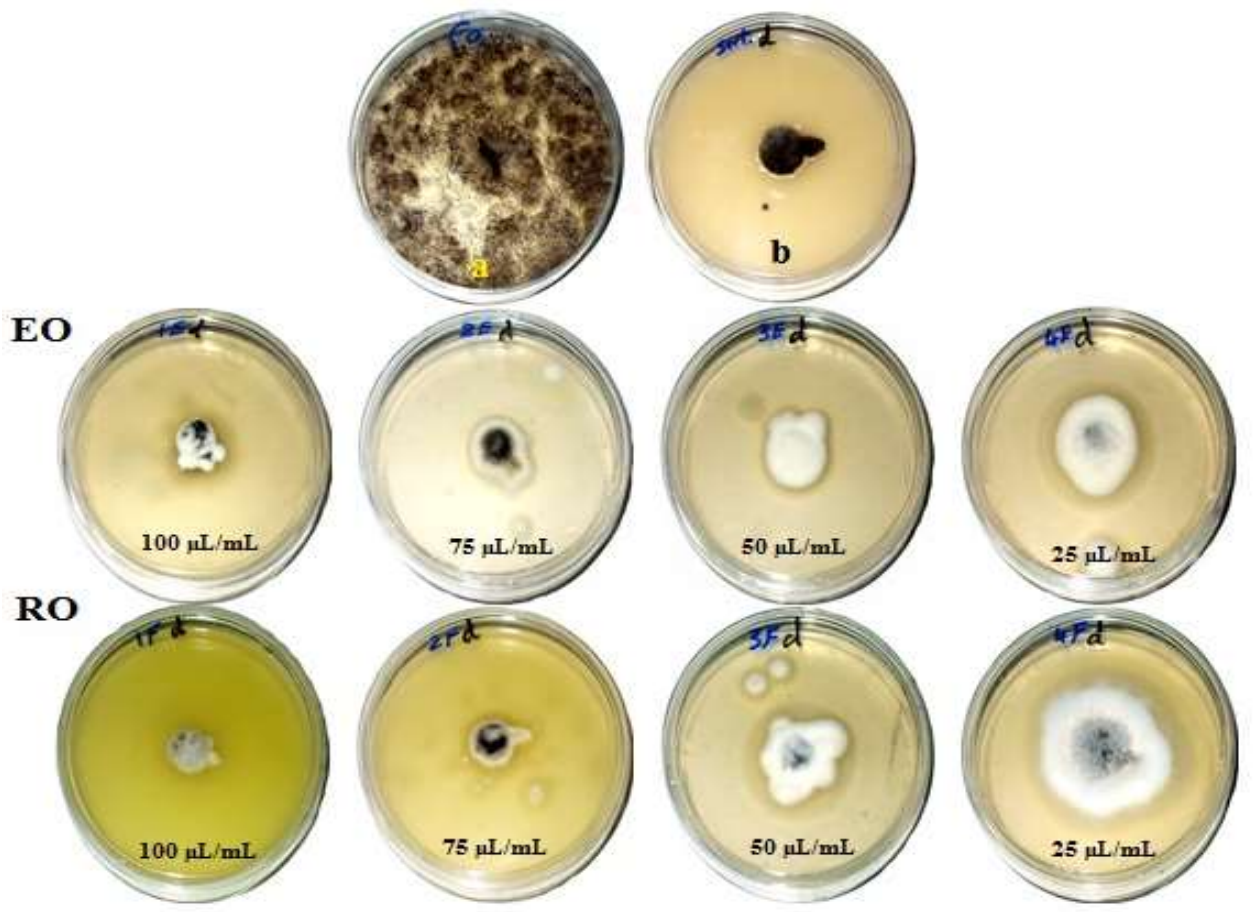

Figure 2. Visual observation of the antifungal activities of essential (EO) and recovery (RO) oils from $M$. chamomilla (flowers) against the growth of Aspergillus niger. (a) Negative control $(0 \mu \mathrm{L} / \mathrm{mL})$; (b) Positive control (Sertaconazol $3 \mathrm{~g} / \mathrm{L}$ ).
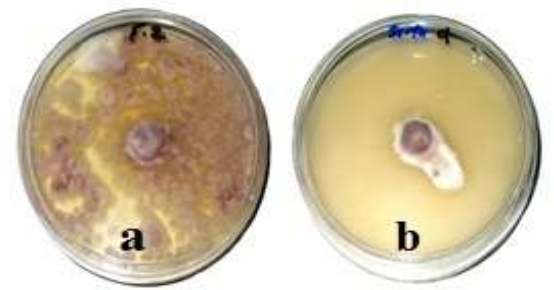

EO
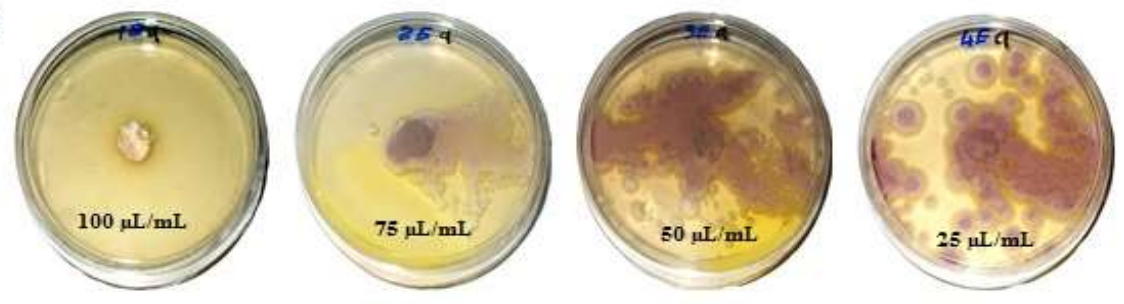

RO
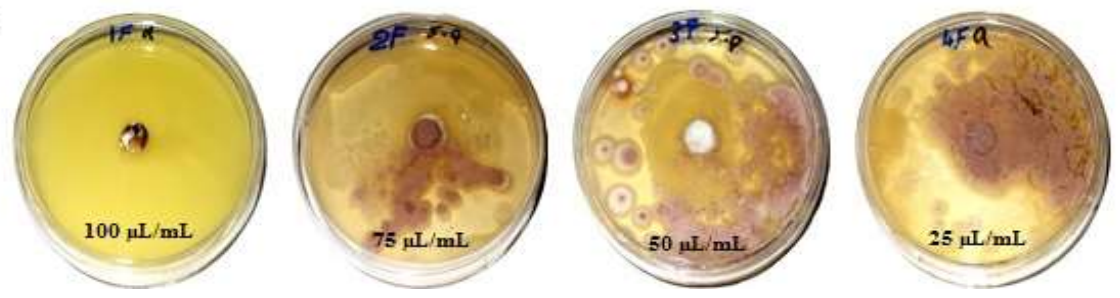

Figure 3. Visual observation of the antifungal activities of essential (EO) and recovery (RO) oils from M. chamomilla (flowers) against the growth of Aspergillus terreus. (a) Negative control $(0 \mu \mathrm{L} / \mathrm{mL})$; (b) Positive control (Sertaconazol $3 \mathrm{~g} / \mathrm{L}$ ). 

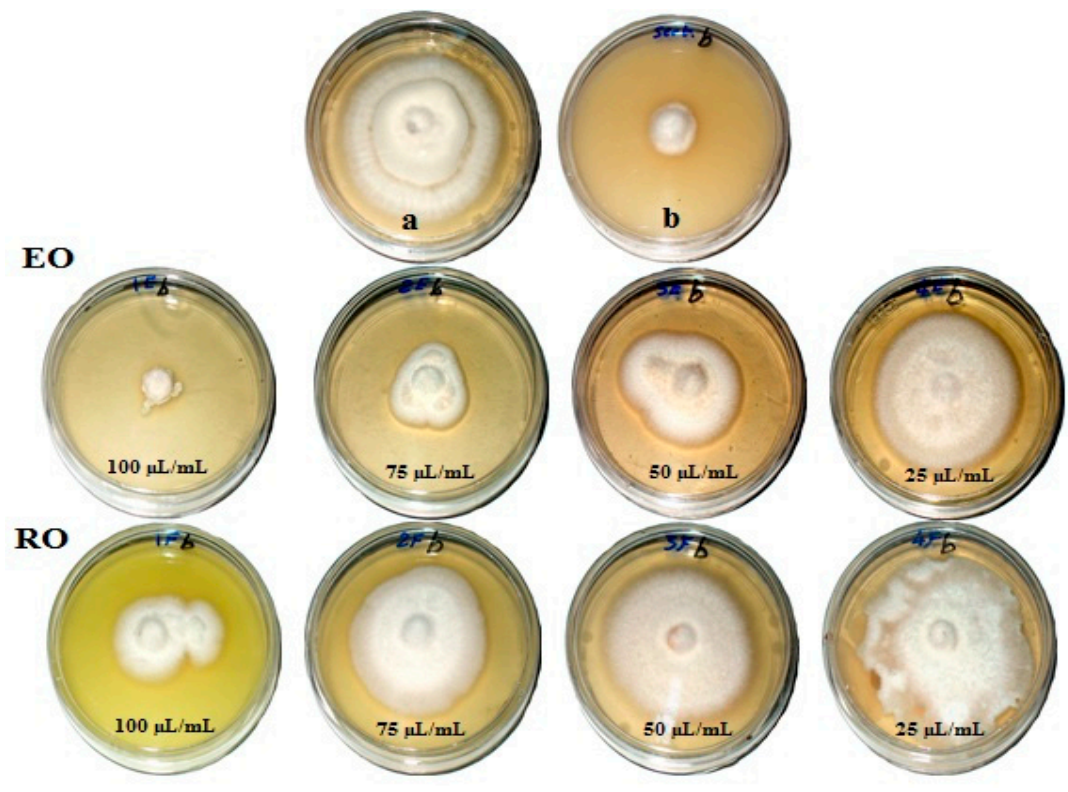

Figure 4. Visual observation of the antifungal activities of essential (EO) and recovery (RO) oils from M. chamomilla (flowers) against the growth of Fusarium culmorum. (a) Negative control $(0 \mu \mathrm{L} / \mathrm{mL})$; (b) Positive control (Sertaconazol $3 \mathrm{~g} / \mathrm{L}$ ).

\subsection{In vitro Antifungal Activity of Essential and Recovery Oils}

Table 2 presents the antifungal activity of essential and recovery oils from the fresh flowers of $M$. chamomilla. Recovery oils, at amounts of 75 and $100 \mu \mathrm{L} / \mathrm{mL}$, showed a fungal mycelial inhibition (FMI) percentage for the growth of $A$. niger, with values of $78 \%$ and $85 \%$, respectively. The same amount of essential oil showed FMI values of $73 \%$ and $84 \%$, respectively. However, these values are lower that the FMI reported by the positive control $(87 \%)$.

Table 2. Inhibition percentage of the diameter growth of A. niger, A. terreus, A. flavus, and F. culmorum as affected by essential and recovery oils from $M$. chamomilla.

\begin{tabular}{|c|c|c|c|c|c|}
\hline \multirow[t]{2}{*}{ Oil Type } & \multirow[b]{2}{*}{$\begin{array}{l}\text { Oil Conc. } \\
\mu \mathrm{L} / \mathrm{mL}\end{array}$} & \multicolumn{4}{|c|}{ Inhibition Percentage of Diameter Growth } \\
\hline & & $\begin{array}{l}\text { Aspergillus } \\
\text { flavus }\end{array}$ & $\begin{array}{c}\text { Aspergillus } \\
\text { terreus }\end{array}$ & $\begin{array}{c}\text { Aspergillus } \\
\text { niger }\end{array}$ & $\begin{array}{l}\text { Fusarium } \\
\text { culmorum }\end{array}$ \\
\hline \multicolumn{2}{|c|}{ Negative control } & 0.00 & 0.00 & 0.00 & 0.00 \\
\hline \multicolumn{2}{|c|}{ Sertaconazol (3 g/L) } & $88.66 \pm 1.15$ & $89.66 \pm 1.52$ & $87 \pm 1$ & $91 \pm 1$ \\
\hline \multirow{4}{*}{ Essential oil } & 25 & $10.66 \pm 5.51$ & $4.33 \pm 1.15$ & $63.33 \pm 2.51$ & $23.33 \pm 2.31$ \\
\hline & 50 & $28.33 \pm 4.16$ & $9.66 \pm 3.21$ & $68.33 \pm 1.52$ & $50 \pm 5$ \\
\hline & 75 & $37.66 \pm 4.51$ & $58.33 \pm 2.51$ & $73 \pm 1.73$ & $65.33 \pm 0.57$ \\
\hline & 100 & $52.33 \pm 2.51$ & 100 & $84 \pm 1$ & $86.66 \pm 0.57$ \\
\hline \multirow{4}{*}{ Recovery oil } & 25 & $4.66 \pm 2.51$ & $7 \pm 2.64$ & $51 \pm 3.61$ & $8 \pm 3$ \\
\hline & 50 & $25 \pm 2$ & $22.66 \pm 0.57$ & $66 \pm 1$ & $30.66 \pm 3.51$ \\
\hline & 75 & $31.33 \pm 3.78$ & $65.66 \pm 1.52$ & $78 \pm 1.73$ & $36 \pm 2$ \\
\hline & 100 & $47.33 \pm 2.51$ & 100 & $85 \pm 2$ & $57.66 \pm 2.51$ \\
\hline$p$-value & & $* *$ & $* *$ & $* *$ & $* *$ \\
\hline
\end{tabular}

Values are means $\pm \mathrm{SD}, * *$ : Highly significant at 0.01 level of probability. 
Both oils, applied at $100 \mu \mathrm{L} / \mathrm{mL}$, showed $100 \%$ FMI of $A$. terreus, higher than the value observed in the positive control (89.66\%). Essential and recovery oils at $75 \mu \mathrm{L} / \mathrm{mL}$ showed FMI of $65.66 \%$ and $58.33 \%$, respectively. Other concentrations showed limited impact on the growth of $A$. terreus. Oils showed limited impact on the growth of $A$. flavus, where all the studied concentrations from both oils presented a much lower FMI than the positive control (88.66\%). Essential and recovery oils at $100 \mu \mathrm{L} / \mathrm{mL}$ showed FMI values of $52.33 \%$ and $47.33 \%$, respectively, against $A$. flavus. Essential oil at $100 \mu \mathrm{L} / \mathrm{mL}$ had good activity against the growth of F. culmorum, with an FMI of $86.66 \%$, and, at 75, $\mu \mathrm{L} / \mathrm{mL}$ with a value of $65.33 \%$, compared to $91 \%$ of positive control (Sertaconazol $3 \mathrm{~g} / \mathrm{L}$ ).

\subsection{Chemical Composition of the Essential and Recovery Oils}

Table 3 presents the chemical composition of the essential oil from $M$. chamomilla (fresh flowers) as analyzed by GC/MS apparatus. The main compounds in the essential oil were (Z)- $\beta$-farnesene $(27.00 \%)$, D-limonene (15.25\%), $\alpha$-bisabolol oxide A $(14.90 \%)$, palmitic acid $(6.44 \%),(E)$-germacrene $\mathrm{D}(3.71 \%)$, $\gamma$-terpinene (3.54\%), and citronellal (3.02\%), while low amounts of chamazulene were observed $(0.73 \%)$.

Table 3. Chemical composition of the essential oil from M. chamomilla (fresh flowers).

\begin{tabular}{|c|c|c|c|c|c|c|}
\hline Compound Name & $\begin{array}{l}\text { Retention } \\
\text { Time (min) }\end{array}$ & $\begin{array}{l}\text { Area } \\
\%\end{array}$ & $\begin{array}{l}\text { Molecular } \\
\text { Formula }\end{array}$ & $\begin{array}{l}\text { Molecular } \\
\text { Weight }\end{array}$ & $\begin{array}{l}\text { Standard } \\
\text { Index }\end{array}$ & $\begin{array}{c}\text { Reverse } \\
\text { Standard Index }\end{array}$ \\
\hline Decane & 3.22 & 0.20 & $\mathrm{C}_{10} \mathrm{H}_{22}$ & 142 & 808 & 916 \\
\hline Sabinene & 3.44 & 0.29 & $\mathrm{C}_{10} \mathrm{H}_{16}$ & 136 & 810 & 823 \\
\hline$\beta$-Pinene & 4.71 & 0.22 & $\mathrm{C}_{10} \mathrm{H}_{16}$ & 136 & 812 & 852 \\
\hline Undecane & 4.77 & 0.24 & $\mathrm{C}_{11} \mathrm{H}_{24}$ & 156 & 861 & 923 \\
\hline Myrcene & 5.79 & 0.37 & $\mathrm{C}_{10} \mathrm{H}_{16}$ & 136 & 856 & 920 \\
\hline D-Limonene & 6.59 & 15.25 & $\mathrm{C}_{10} \mathrm{H}_{16}$ & 136 & 924 & 924 \\
\hline Tetradecane & 6.92 & 0.35 & $\mathrm{C}_{14} \mathrm{H}_{30}$ & 198 & 877 & 929 \\
\hline$\gamma$-Terpinene & 7.64 & 3.54 & $\mathrm{C}_{10} \mathrm{H}_{16}$ & 136 & 934 & 944 \\
\hline m-Cymene & 8.21 & 0.71 & $\mathrm{C}_{10} \mathrm{H}_{14}$ & 134 & 908 & 944 \\
\hline Ocimene & 8.52 & 0.23 & $\mathrm{C}_{10} \mathrm{H}_{16}$ & 136 & 858 & 865 \\
\hline Citronellal & 13.54 & 3.02 & $\mathrm{C}_{10} \mathrm{H}_{18} \mathrm{O}$ & 154 & 948 & 950 \\
\hline Linalool & 15.21 & 0.21 & $\mathrm{C}_{10} \mathrm{H}_{18} \mathrm{O}$ & 154 & 899 & 936 \\
\hline Isopulegol & 15.77 & 0.26 & $\mathrm{C}_{10} \mathrm{H}_{18} \mathrm{O}$ & 154 & 898 & 951 \\
\hline$\beta$-Caryophyllene & 16.47 & 0.87 & $\mathrm{C}_{15} \mathrm{H}_{24}$ & 204 & 920 & 944 \\
\hline Aromadendrene & 17.61 & 0.22 & $\mathrm{C}_{15} \mathrm{H}_{24}$ & 204 & 853 & 915 \\
\hline (Z)- $\beta$-farnesene & 18.29 & 27.00 & $\mathrm{C}_{15} \mathrm{H}_{24}$ & 204 & 928 & 929 \\
\hline$\alpha$-Muurolene & 18.71 & 0.35 & $\mathrm{C}_{15} \mathrm{H}_{24}$ & 204 & 854 & 886 \\
\hline$\alpha$-Terpineol & 18.82 & 0.73 & $\mathrm{C}_{10} \mathrm{H}_{18} \mathrm{O}$ & 154 & 853 & 894 \\
\hline Chamazulene & 32.98 & 0.73 & $\mathrm{C}_{14} \mathrm{H}_{16}$ & 184 & 781 & 815 \\
\hline (E)-Germacrene D & 19.15 & 3.71 & $\mathrm{C}_{15} \mathrm{H}_{24}$ & 204 & 947 & 954 \\
\hline$(Z, E)-\alpha$-Farnesene & 19.55 & 0.95 & $\mathrm{C}_{15} \mathrm{H}_{24}$ & 204 & 905 & 931 \\
\hline Lepidozene & 19.68 & 1.61 & $\mathrm{C}_{15} \mathrm{H}_{24}$ & 204 & 898 & 905 \\
\hline$\alpha$-Farnesene & 20.08 & 5.62 & $\mathrm{C}_{15} \mathrm{H}_{24}$ & 204 & 949 & 955 \\
\hline$\Delta$-Cadinene & 20.22 & 0.66 & $\mathrm{C}_{15} \mathrm{H}_{24}$ & 204 & 886 & 929 \\
\hline Citronellol & 20.37 & 1.00 & $\mathrm{C}_{10} \mathrm{H}_{20} \mathrm{O}$ & 156 & 907 & 917 \\
\hline Diethylene glycol & 24.90 & 0.39 & $\mathrm{C}_{4} \mathrm{H}_{10} \mathrm{O}_{3}$ & 106 & 818 & 891 \\
\hline $\begin{array}{l}\text { 2,5-Octadecadiynoic acid methyl } \\
\text { ester }\end{array}$ & 26.12 & 0.20 & $\mathrm{C}_{19} \mathrm{H}_{30} \mathrm{O}_{2}$ & 290 & 686 & 692 \\
\hline Dimethyl anthranilate & 26.88 & 0.69 & $\mathrm{C}_{9} \mathrm{H}_{11} \mathrm{NO}_{2}$ & 165 & 676 & 721 \\
\hline Viridiflorol & 27.05 & 0.20 & $\mathrm{C}_{15} \mathrm{H}_{26} \mathrm{O}$ & 222 & 795 & 894 \\
\hline Spathulenol & 27.84 & 0.39 & $\mathrm{C}_{15} \mathrm{H}_{24} \mathrm{O}$ & 220 & 801 & 852 \\
\hline$\alpha$-Bisabolol oxide B & 28.05 & 0.86 & $\mathrm{C}_{15} \mathrm{H}_{26} \mathrm{O}_{2}$ & 238 & 855 & 891 \\
\hline Bisabolone oxide & 28.85 & 0.58 & $\mathrm{C}_{15} \mathrm{H}_{24} \mathrm{O}_{2}$ & 236 & 781 & 850 \\
\hline $\begin{array}{l}\text { 2'-Hexyl-1,1'-bicyclopropane-2-octanoic } \\
\text { acid methyl ester }\end{array}$ & 29.02 & 0.18 & $\mathrm{C}_{21} \mathrm{H}_{38} \mathrm{O}_{2}$ & 322 & 695 & 709 \\
\hline$\alpha$-Bisabolol & 29.61 & 0.32 & $\mathrm{C}_{15} \mathrm{H}_{26} \mathrm{O}$ & 222 & 773 & 889 \\
\hline$\alpha$-Cadinol & 29.88 & 0.26 & $\mathrm{C}_{15} \mathrm{H}_{26} \mathrm{O}$ & 222 & 757 & 823 \\
\hline$\alpha$-Bisabolol oxide A & 33.44 & 14.90 & $\mathrm{C}_{15} \mathrm{H}_{26} \mathrm{O}_{2}$ & 238 & 858 & 870 \\
\hline Palmitic acid & 36.25 & 6.44 & $\mathrm{C}_{16} \mathrm{H}_{32} \mathrm{O}_{2}$ & 256 & 850 & 877 \\
\hline
\end{tabular}

Table 4 presents the chemical compounds identified in the recovery oil from the hydrodistillation of M. chamomilla fresh flowers. The main compounds were $\alpha$-bisabolol oxide A $(18.60 \%)$, D-limonene $(8.82 \%)$, 
$\alpha$-bisabolol oxide B (7.13\%), dodecane (5.92\%), $\alpha$-farnesene (5.16\%), undecane (5.03\%), oleic acid (4.51\%), citronellal (4.24\%), bisabolone oxide (3.81\%), $\alpha$-terpineol (3.73\%), and chamazulene $(3.50 \%)$.

Table 4. Chemical composition of the recovered oil M. chamomilla (fresh flowers).

\begin{tabular}{ccccccc}
\hline Compound Name & $\begin{array}{c}\text { Retention } \\
\text { Time (min) }\end{array}$ & $\begin{array}{c}\text { Area } \\
\%\end{array}$ & $\begin{array}{c}\text { Molecular } \\
\text { Formula }\end{array}$ & $\begin{array}{c}\text { Molecular } \\
\text { Weight }\end{array}$ & $\begin{array}{c}\text { Standard } \\
\text { Index }\end{array}$ & $\begin{array}{c}\text { Reverse } \\
\text { Standard Index }\end{array}$ \\
\hline 5-Ethyl-2-nonanol & 3.35 & 0.52 & $\mathrm{C}_{11} \mathrm{H}_{24} \mathrm{O}$ & 172 & 730 & 744 \\
1-Isobutyl-3-methyl-cyclopentane & 3.46 & 0.39 & $\mathrm{C}_{10} \mathrm{H}_{20}$ & 140 & 710 & 771 \\
Undecane & 4.76 & 5.03 & $\mathrm{C}_{11} \mathrm{H}_{24}$ & 156 & 899 & 944 \\
1-Hexadecanol, 2-methyl- & 5.11 & 0.69 & $\mathrm{C}_{17} \mathrm{H}_{36} \mathrm{O}$ & 256 & 759 & 762 \\
2-methyl undecane & 5.95 & 1.11 & $\mathrm{C}_{12} \mathrm{H}_{26}$ & 170 & 835 & 892 \\
Decyl Ether & 6.15 & 0.58 & $\mathrm{C}_{20} \mathrm{H}_{42} \mathrm{O}$ & 298 & 789 & 804 \\
D-Limonene & 6.55 & 8.82 & $\mathrm{C}_{10} \mathrm{H}_{16}$ & 136 & 904 & 915 \\
Dodecane & 6.92 & 5.92 & $\mathrm{C}_{12} \mathrm{H}_{26}$ & 170 & 923 & 929 \\
2,6,10,14-Tetramethylheptadecane & 8.24 & 1.00 & $\mathrm{C}_{21} \mathrm{H}_{44}$ & 296 & 790 & 843 \\
Nonadecane & 8.35 & 1.54 & $\mathrm{C}_{19} \mathrm{H}_{40}$ & 268 & 789 & 869 \\
Citronellal & 13.56 & 4.24 & $\mathrm{C}_{10} \mathrm{H}_{18} \mathrm{O}$ & 154 & 800 & 820 \\
Chamazulene & 18.26 & 3.50 & $\mathrm{C}_{15} \mathrm{H}_{24}$ & 204 & 912 & 930 \\
$\alpha$-Terpineol & 18.85 & 3.73 & $\mathrm{C}_{10} \mathrm{H}_{18} \mathrm{O}$ & 154 & 790 & 796 \\
$\alpha$-Farnesene & 20.05 & 5.16 & $\mathrm{C}_{15} \mathrm{H}_{24}$ & 204 & 916 & 941 \\
2-(2-Hydroxyethoxy)ethanol & 24.90 & 1.60 & $\mathrm{C}_{4} \mathrm{H}_{10} \mathrm{O}_{3}$ & 106 & 849 & 883 \\
$\alpha$-Bisabolol oxide B & 28.05 & 7.13 & $\mathrm{C}_{15} \mathrm{H}_{26} \mathrm{O}_{2}$ & 238 & 824 & 870 \\
Bisabolone oxide & 28.84 & 3.81 & $\mathrm{C}_{15} \mathrm{H}_{24} \mathrm{O}_{2}$ & 236 & 728 & 809 \\
Cyclopropanetetradecanoic acid, & 30.62 & 0.46 & $\mathrm{C}_{26} \mathrm{H}_{50} \mathrm{O}_{2}$ & 394 & 738 & 750 \\
2-octyl-methyl ester & 33.08 & 18.60 & $\mathrm{C}_{15} \mathrm{H}_{26} \mathrm{O}_{2}$ & 238 & 852 & 870 \\
$\alpha$-Bisabolol oxide A & 33.17 & 4.51 & $\mathrm{C}_{18} \mathrm{H}_{34} \mathrm{O}_{2}$ & 282 & 744 & 844 \\
Oleic acid & 34.00 & 1.38 & $\mathrm{C}_{14} \mathrm{H}_{30} \mathrm{O}_{8}$ & 326 & 775 & 811 \\
Heptaethylene glycol & & & & & & \\
\hline
\end{tabular}

\section{Discussion}

In the present study, essential and recovery oils from $M$. chamomilla fresh flowers were reported to have potential antifungal activity against the growth of fungi associated with the biodeterioration of cultural heritage (Aspergillus niger, A. terreus, A. flavus, and Fusarium culmorum).

These activities could be significantly related to the main identified compounds in both oils, such as (Z)- $\beta$-farnesene, D-limonene, $\alpha$-bisabolol oxide A, $\alpha$-bisabolol oxide $\mathrm{B}$, and even chamazulene, which was present in low amounts.

The main identified compounds in the essential oil of $M$. chamomilla fresh flowers were (Z)- $\beta$-farnesene, D-limonene, $\alpha$-bisabolol oxide A, and palmitic acid, with quantities of $27 \%, 15.25 \%, 14.9 \%$, and $6.4 \%$, respectively. In the recovery oil, the main compounds were $\alpha$-bisabolol oxide $\mathrm{A}, \mathrm{D}$-limonene, and $\alpha$-bisabolol oxide B, with amounts of $18.60 \%, 8.82 \%$, and $7.13 \%$, respectively. The identified main compound ( $\alpha$-bisabolol oxide $\mathrm{A})$ is much higher than the isolated compound from the Iranian Camomille, which reached $2.19 \%$ [26] and was recognized by the $\alpha$-bisabolol (56.86\%) and trans, trans-Farnesol (15.64\%) as a chemotype. Another study [41] showed that $\alpha$-bisabolol oxide (38\%), camphene $(9.11 \%)$, sabinene (4.87\%), limonene (6\%), 1,8-cineole (7.12\%), camphor (6.54\%), and $\alpha$-pinene (6\%) were the main compounds of the essential oil, from aerial parts of the M. recutita. Chamazulene was identified in low amounts $(0.73 \%$, and $3.50 \%$, in essential and recovery oils, respectively). This agrees with Tolouee et al. [26] who found that chamazulene was identified in the essential oil from flowers of $M$. chamomilla with amounts of $2.18 \%$, while it reached $61.3 \%$ in the essential oil of $M$. chamomilla flower [32].

Our results agreed with the study of Satyal [42] who found that (E)- $\beta$-farnesene, $\alpha$-bisabolol oxide $\mathrm{A},(E, E)-\alpha$-farnesene, and $\alpha$-bisabolol oxide $\mathrm{B}$, and $\alpha$-bisabolone oxide A were the main compounds of Nepalese chamomile oil, at quantities of $42.2,22.3,8.3,4.5$ and 4, respectively, and demonstrated good antimicrobial activity. Several studies presented the main compounds of the essential oil from $M$. chamomilla flowers as (E)- $\beta$-farnesene, chamazulene, $\alpha$-bisabolol, $\alpha$-bisabolol oxides A, and $\alpha$-bisabolol oxides $\mathrm{B}$, in the ranges of $4.9-8.1 \%, 2.3-10.9 \%, 4.8-11.3 \%, 25.5-28.7 \%$, and $12.2-30.9 \%$, respectively $[29,43-45]$. The bioactive compounds showed strong antifungal activity against both 
phyto and medical pathogenic fungi $[26,46,47]$. The flower's essential oil showed potential antifungal activity against $A$. flavus, A. fumigatus, A. niger, F. oxysporum and Trichoderma harzianum [32]. EO, with its high content of $\alpha$-bisabolol oxide A (48.22\%), $\alpha$-bisabolol oxide B (23.31\%), and $\alpha$-bisabolol (12.1\%), and low chamazulene content $(2.42 \%)$ demonstrated good antifungal activity against $A$. flavus and C. albicans [48]. An $\alpha$-bisabolol-rich $M$. chamomilla oil showed antifungal activity against $A$. niger at concentrations above $125 \mu \mathrm{g} / \mathrm{mL}$ and the oil inhibited hyphal growth and conidial production [26]. However, some reports showed that the essential oils and extracts from $M$. chamomilla have moderate to weak activities against the growth of fungi [15,49-51].

Recent work showed that the $n$-hexane oily extract of air-dried flowers had the following main compounds: bisabolol oxide A, (Z)- $\beta$-farnesene, 4-isopropenyl-1-methyl-cyclohexene, chamazulene, D-limonene, $(R)-(+)$-citronellal, and $\gamma$-terpinene, with values of $16.60 \%, 16.11 \%, 14.18 \%, 11.27 \%, 4.82 \%$, $3.65 \%$ and $3.07 \%$ ), respectively [15]. However, when applied to wood, weak activity against the fungal infestation of Fusarium culmorum, Rhizoctonia solani, and Penicillium chrysogenum was found 15].

It was reported that the two most prominent compounds found in oils of M. chamomilla, farnesol and $\alpha$-bisabolol, have potential antifungal activity [52]. $\beta$-farnesene, $\alpha$-farnesene, and $\alpha$-bisabolol and its oxide were reported as its main compounds [53,54]. Essential oils with these were observed to have good antifungal activity against $A$. niger, Aspergillus sp. and Candida albicans [55]. An oil rich in $\alpha$-bisabolol oxide A, extracted from M. chamomilla flowers from Neyshabur, Iran, showed potential activity against B. cereus, S. aureus, and Proteus vulgaris [56].

There are several reports regarding the use of natural products in the field of cultural heritage conservation [2]. EOs of Pimpinella anisum and Allium sativum showed the best antifungal activity against fungal strains isolated from Cuban and Argentine Documentary Heritage, including A. niger, A. clavatus, Penicillium sp. and Fusarium sp. [57].

Finally, it could be concluded that from the above data and from the literature, the essential oil from M. chamomilla flowers has a potential antifungal activity and, notably, that the recovered oil also showed potent antifungal activity.

\section{Conclusions}

This study highlighted the importance of using essential and recovery oils from fresh flowers of Matricaria chamomilla. Both oils presented potential bioactive molecules in their chemical compositions, demonstrating activity against the growth of four fungi isolated from cultural heritage objects. Interestingly, our results identified novel and strong antifungal agents against four deteriorating fungi by applying the recovery oil, which could be considered as an alternative source for the production of commercial antifungal agents. Further studies are required to develop new methods to apply the oils in the field of cultural heritage preservation.

Author Contributions: M.E.-H. and W.A.A.A.E. designed and carried out the methodology, as well as conducted laboratory analyses; A.A.A.-H. and H.M.A. contributed reagents/materials/analytical tools, and all the authors shared in writing and revising the article.

Funding: This research was funded by the Deanship of Scientific Research, King Saud University, through the Vice Deanship of Scientific Research Chairs.

Acknowledgments: The authors are grateful to the Deanship of Scientific Research, King Saud University, for funding through the Vice Deanship of Scientific Research Chairs. The authors also thank the Deanship of Scientific Research and RSSU at King Saud University for their technical support.

Conflicts of Interest: The authors declare no conflict of interest.

\section{References}

1. Sterflinger, K. Fungi: Their role in deterioration of cultural heritage. Fungal Biol. Rev. 2010, 24, 47-55. [CrossRef] 
2. Stupar, M.; Grbić, M.L.; Džamić, A.; Unković, N.; Ristić, M.; Jelikić, A.; Vukojević, J. Antifungal activity of selected essential oils and biocide benzalkonium chloride against the fungi isolated from cultural heritage objects. S. Afr. J. Bot. 2014, 93, 118-124. [CrossRef]

3. Breuil, C. Wood as a nutritional resource for staining fungi. In Biology and Prevention of Sapstain; Forest Products Society: Madison, GA, USA, 1998; pp. 1-6.

4. Mansour, M.M.; Salem, M.Z.M. Evaluation of wood treated with some natural extracts and Paraloid B-72 against the fungus Trichoderma harzianum: Wood elemental composition, in-vitro and application evidence. Int. Biodeterior. Biodegr. 2015, 100, 62-69. [CrossRef]

5. Xu, K.; Feng, J.; Zhong, T.; Zheng, Z.; Chen, T. Effects of volatile chemical components of wood species on mould growth susceptibility and termite attack resistance of wood plastic composites. Int. Biodeterior. Biodegr. 2015, 100, 106-115. [CrossRef]

6. Mesquita, N.; Portugal, A.; Videira, S.; Rodríguez-Echeverría, S.; Bandeira, A.M.L.; Santos, M.J.A.; Freitas, H. Fungal diversity in ancient documents. A case study on the archive of the University of Coimbra. Int. Biodeterior. Biodegr. 2009, 63, 626-629. [CrossRef]

7. Salem, M.Z.M. EDX measurements and SEM examination of surface of some imported woods inoculated by three mold fungi. Measurement 2016, 86, 301-309. [CrossRef]

8. Salem, M.Z.M.; Zidan, Y.E.; Mansour, M.M.A.; El Hadidi, N.M.N.; Abo Elgat, W.A.A. Evaluation of usage three natural extracts applied to three commercial wood species against five common molds. Int. Biodeterior. Biodegr. 2016, 110, 206-226. [CrossRef]

9. Salem, M.Z.M.; Zidan, Y.E.; Mansour, M.M.A.; El Hadidi, N.M.N.; Abo Elgat, W.A.A. Antifungal activities of two essential oils used in the treatment of three commercial woods deteriorated by five common mold fungi. Int. Biodeterior Biodegr. 2016, 106, 88-96. [CrossRef]

10. Görs, S.; Schumann, R.; Häubner, N.; Karsten, U. Fungal and algal biomass in biofilms on artificial surfaces quantified by ergosterol and chlorophyll a as biomarkers. Inter. Biodeterior. Biodegrad. 2007, 60, 50-59. [CrossRef]

11. Stupar, M.; Grbić, M.L.; Simić, G.S.; Jelikić, A.; Vukojević, J.; Sabovljević, M. A sub-aerials biofilms investigation and new approach in biocide application in cultural heritage conservation: Holly Virgin Church (Gradac Monastery, Serbia). Ind. Built Environ. 2012, 23, 584-593. [CrossRef]

12. Behiry, S.I.; Okla, M.K.; Alamri, S.A.; EL-Hefny, M.; Salem, M.Z.M.; Alaraidh, I.A.; Ali, H.M.; Al-Ghtani, S.M.; Monroy, J.C.; Salem, A.Z.M. Antifungal and antibacterial activities of Musa paradisiaca L. peel extract: HPLC analysis of phenolic and flavonoid contents. Processes 2019, 7, 215. [CrossRef]

13. Okla, M.K.; Alamri, S.A.; Salem, M.Z.M.; Ali, H.M.; Behiry, S.I.; Nasser, R.A.; Alaraidh, I.A.; Al-Ghtani, S.M.; Soufan, W. Yield, phytochemical constituents, and antibacterial activity of essential oils from the leaves/twigs, branches, branch wood, and branch bark of Sour Orange (Citrus aurantium L.). Processes 2019, 7, 363. [CrossRef]

14. Salem, M.Z.M.; Mansour, M.M.A.; Elansary, H.O. Evaluation of the effect of inner and outer bark extracts of Sugar Maple (Acer saccharum var. saccharum) in combination with citric acid against the growth of three common molds. J. Wood Chem. Technol. 2019, 39, 136-147. [CrossRef]

15. Salem, M.Z.M.; Behiry, S.I.; EL-Hefny, M. Inhibition of Fusarium culmorum, Penicillium chrysogenum and Rhizoctonia solani by n-hexane extracts of three plant species as a wood-treated oil fungicide. J. Appl. Microbiol. 2019, 126, 1683-1699. [CrossRef] [PubMed]

16. Astiti, N.P.A.; Suprapta, D.N. Antifungal activity of teak (Tectona grandis L.F.) against Arthrinium phaeospermum (Corda) M.B. Ellis, the cause of wood decay on Albizia falcataria (L.) Fosberg. J. Int. Soc. Southeast. Asian Agric. Sci. 2012, 18, 62-69.

17. Pinto, E.; Vale-Silva, L.; Cavaleiro, C.; Salgueiro, L. Antifungal activity of the clove essential oil from Syzygium aromaticum on Candida, Aspergillus and dermatophyte species. J. Med. Microbiol. 2009, 58, 1454-1462. [CrossRef]

18. Rana, I.S.; Rana, A.S.; Rajak, R.C. Evaluation of antifungal activity in essential oil of the Syzygium aromaticum (L.) by extraction, purification and analysis of its main component eugenol. Braz. J. Microbiol. 2011, 42, 1269-1277. [CrossRef]

19. Hamad, Y.K.; Abobakr, Y.; Salem, M.Z.M.; Ali, H.M.; Al-Sarar, A.S.; Al-Zabib, A.A. Activity of plant extracts/essential oils against some plant pathogenic fungi and mosquitoes: GC/MS analysis of bioactive compounds. BioResources 2019, 14, 4489-4511. 
20. Ivens, G.M. Stinking mayweed. N. Z. J. Agric. 1979, 138, 21-23.

21. Svab, J. New aspects of cultivating chamomile. Herba Polonica 1979, 25, 35-39.

22. Issac, O. Recent Progress in Chamomile Research-Medicines of Plant Origin in Modern Therapy, 1st ed.; Prague Press: Geneva, Switzerland, 1989.

23. Bradley, P. The British Herbal Compendium, 1st ed.; British Herbal Medicine Association: London, UK, 1992.

24. Mann, C.; Staba, E.J. The chemistry, pharmacology and commercial formulations of chamomile. In Herbs, Spices and Medicinal Plants-Recent Advances in Botany, Horticulture and Pharmacology; Craker, L.E., Simon, J.E., Eds.; Haworth Press Inc.: Philadelphia, PA, USA, 2002; pp. 235-280.

25. Berry, M. Herbal products. Part 6. Chamomiles. Pharmaceut. J. 1995, 254, 191-193.

26. Tolouee, M.; Alinezhad, S.; Saberi, R.; Eslamifar, A.; Zad, S.J.; Jaimand, K. Effect of Matricaria chamomilla L. flower essential oil on the growth and ultrastructure of Aspergillus niger van Tieghem. Int. J. Food Microbiol. 2010, 139, 127-133. [CrossRef] [PubMed]

27. Falzari, L.M.; Menary, R.C. Chamomile for Oil and Dried Flowers; RIRDC Publication No. 02/156 RIRDC Project No. UT-28 A; Rural Industries Research and Development Corporation, RIRDC Publication: Canberra, Australia, 2003.

28. Guenther, E. The Essential Oil, 1st ed.; D. Van Nostrand Company Inc.: New York, NY, USA, 1952.

29. Schilcher, H.; Imming, P.; Goeters, S. Active chemical constituents of Matricaria chamomilla L. syn. Chamomilla recutita (L.) Rauschert. In Chamomile Industrial Profiles; Franke, R., Schilcher, H., Eds.; CRC Press: Boca Raton, FL, USA, 2005; pp. 55-76.

30. Reichling, J.; Beiderbeck, R.; Becker, H. Vergleichende Untersuchungen Uber sekundare Inhaltsstoffe bei pflanzentumoren, Blite Kraut und wurzel der Matricaria chamomilla L. Planta Med. 1979, 36, 322-332. [CrossRef]

31. Reichling, J.; Bisson, W.; Becker, H.; Schilling, G. Zusammensetzung und accumulation des etherischenol in Matricaria chamomilla Radix. 2. Mitt. Z. Naturforsch 1983, 38, 159-161. [CrossRef]

32. Jamalian, A.; Shams-Ghahfarokhi, M.; Jaimand, K.; Pashootan, N.; Amani, A.; Razzaghi-Abyaneh, M. Chemical composition and antifungal activity of Matricaria recutita flower essential oil against medically important dermatophytes and soil-borne pathogens. J. Mycol. Méd. 2012, 22, 308-315. [CrossRef]

33. Isaac, O. Therapy with chamomile-experience and verification. Disch Apoth Ztg. 1980, 120, 567-570.

34. Manday, E.; Szoke, E.; Muskath, Z.; Lemberkovics, E. A study of the production of essential oils in chamomile hairy root cultures. Eur. J. Drug. Metab Pharmacokinet. 1999, 24, 303-308.

35. Duke, J.A. CRC Handbook of Medicinal Herbs, 1st ed.; CRC Press: Boca Raton, FL, USA, 1985; pp. $297-414$.

36. Saitoh, K.; Togashi, K.; Arie, T.; Teraoka, T. A simple method for a mini-preparation of fungal DNA. J. Gen. Plant. Pathol. 2006, 72, 348-350. [CrossRef]

37. Taha, A.S.; Abo Elgat, W.A.A.; Salem, M.Z.M.; Ali, H.M.; Fares, Y.G.E.; Elshikh, M.S. Impact of some plant source additives on enhancing the properties and antifungal activities of pulp made from linen fibers. BioResources 2019, 14, 6025-6046.

38. Abdelsalam, N.R.; Salem, M.Z.M.; Ali, H.M.; Mackled, M.I.; EL-Hefny, M.; Elshikh, M.S.; Hatamleh, A.A. Morphological, biochemical, molecular, and oil toxicity properties of Taxodium trees from different locations. Ind. Crops Prod. 2019, 139, 111515. [CrossRef]

39. Pandey, D.K.; Tripathi, N.N.; Tripathi, R.D.; Dixit, S.N. Fungitoxic and phytotoxic properties of the essential oil of Hyptis suaveolens. J. Plant. Dis. Prot. 1982, 89, 344-349.

40. SAS. User Guide: Statistics (Release 8.02); SAS Institute: Cary, NC, USA, 2001.

41. Kazemi, M. Chemical composition and antimicrobial activity of essential oil of Matricaria recutita. Int. J. Food Propert. 2015, 18, 1784-1792. [CrossRef]

42. Satyal, P.; Shrestha, S.; Setzer, W.N. Composition and bioactivities of an (E)- $\beta$-farnesene chemotype of Chamomile (Matricaria chamomilla) essential oil from Nepal. Nat. Prod. Commun. 2015, 10, 1453-1457. [CrossRef] [PubMed]

43. Misra, N.; Luthra, R.; Singh, K.L.; Kumar, S.; Kiran, L. Recent advances in biosynthesis of alkaloids. In Comprehensive Natural Product Chemistry (CONAP); Nanishi, K., Methcohn, O., Eds.; Elsevier Publisher: Oxford, UK, 1999; pp. 25-69.

44. Gasic, O.; Lukic, V.; Nikolic, A. Chemical study of Matricaria chamomilla L-II. Fitoterapia 1983, 54, 51-55.

45. Wagner, H.; Bladt, S.; Zgainski, E.M. Plant Drug Analysis, 1st ed.; Springer: Heidelberg, Germany, 1984; pp. 32-34. 
46. Soliman, K.M.; Badeaa, R.I. Effect of oil extracted from some medicinal plants on different mycotoxigenic fungi. Food Chem Toxicol. 2002, 40, 1669-1675. [CrossRef]

47. Magro, A.; Carolino, M.; Bastos, M.; Mexia, A. Efficacy of plant extracts against stored products fungi. Revista Iberoam Micol. 2006, 23, 176-178. [CrossRef]

48. Roby, M.H.H.; Sarhan, M.A.; Selim, K.A.H.; Khalel, K.I. Antioxidant and antimicrobial activities of essential oil and extracts of fennel (Foeniculum vulgare L.) and chamomile (Matricaria chamomilla L.). Ind. Crop. Prod. 2013, 44, 437-445. [CrossRef]

49. Dulger, B.; Gonuz, A. Antimicrobial activity of certain plants used in Turkish traditional medicine. Asian J. Plant. Sci. 2004, 3, 104-107.

50. El-Mougy, N.; Abdel-Kader, M. Antifungal effect of powdered spices and their extracts on growth and activity of some fungi in relation to damping-off disease control. J. Plant. Prot. Res. 2007, 47, 3-10.

51. Lee, S.O.; Choi, G.J.; Jang, K.S.; Lim, H.K.; Cho, K.Y.; Kim, J.C. Antifungal activity of five essential oils as fumigant against postharvest and soil-borne plant pathogenic fungi. Plant. Pathol. J. 2007, 23, 97-102. [CrossRef]

52. Pauli, A.; Schilcher, H. Specific selection of essential oil compounds for treatment of children's infection disease. Pharma 2004, 1, 1-30. [CrossRef]

53. Šavikin, K.; Menkovic, N.; Ristic, M.; Arsic, I.; Zdunic, G.; Đorðevic, S.; Cujiæ, N.; Švecová, E.; Proietti, S.; Caruso, C.; et al. Antifungal activity of Vitex agnus-castus extract against Pythium ultimum in tomato. Crop. Prot. 2013, 43, 223-230.

54. Stanojevic, L.P.; Marjanovic-Balaban, Z.R.; Kalaba, V.D.; Stanojevic, J.S.; Cvetkovic, D.J. Chemical composition, antioxidant and antimicrobial activity of chamomile flowers essential oil (Matricaria chamomilla L.). J. Essent. Oil Bear. Plants 2016, 19, 2017-2028. [CrossRef]

55. Abdoul-Latif, F.M.; Mohamed, N.; Edou, P.; Ali, A.A.; Djama, S.O.; Obame, L.C.; Bassolé, I.H.N.; Dicko, M.H. Antimicrobial and antioxidant activities of essential oil and methanol extract of Matricaria chamomilla L. from Djibouti. J. Med. Plants Res. 2011, 5, 1512-1517.

56. Alireza, M. Antimicrobial activity and chemical composition of essential oils of chamomile from Neyshabur, Iran. J. Med. Plants Res. 2012, 6, 820-824.

57. Borego, S.; Valdés, O.; Vivar, I.; Lavin, P.; Guiamet, P.; Battistoni, P.; de Saravia, S.G.; Borges, P. Essential oils of plants as biocides against microorganisms isolated from Cuban and Argentine documentary heritage. ISRN Microbiol. 2012. [CrossRef] 